\title{
Immuno-histochemical and -cytochemical Evidence Suggesting the Presence of Campylobacter jejuni and Campylobacter coli in Cases of Porcine Intestinal Adenomatosis
}

\author{
By Karin Eriksen, Thor Landsverk, Bjørn Gondrosen and Jorunn Vormeland \\ Department of Pathology, Department of Food Hygiene, \\ Norwegian College of Veterinary Medicine and the National Veterinary Institute, \\ Oslo, Norway.
}

\begin{abstract}
Eriksen, K., T. Landsverk, B. Gondrosen and J. Vormeland: Immuno-histochemical and-cytochemical evidence suggesting the presence of Campylobacter jejuni and Campylobacter coli in cases of porcine intestinal adenomatosis. Acta vet. scand. $1990,31,445-451$. - Antisera against a number of Campylobacter species were used in immuno-histochemical and -cytochemical studies on cases of porcine intestinal adenomatosis. Avidin-biotin-complex $(\mathrm{ABC})$ and streptavidin immunoperoxidase methods were used on formalin-fixed, paraffin-embedded and frozen sections. Protein A gold method was used on formaldehyde fixed and frozen sections for immuno-cytochemistry. The antisera used were raised in rabbits by subcutaneous or intravenous injection of living or formalin treated organisms. Antisera against different serotypes of the thermotolerant, catalase positive campylobacters, Campylobacter jejuni and Campylobacter coli, gave positive reactions in the immuno-histochemical studies. The staining was found in intestinal epithelial cells both in the ileum and in the colon and was restricted to the apical cytoplasm of adenomatous epithelial cells. The staining had a granular pattern, the positive structures sometimes having the shape of Campylobacter. Epithelial cells in areas with normal differentiation of goblet cells did not stain. In contrast, no staining resulted with antisera against Campylobacter sputorum subsp. mucosalis and Campylobacter hyointestinalis. Immuno-cytochemistry, using antisera against Campylobacter jejuni, showed that the positive staining in altered epithelial cells were restricted to intracellular organisms having a structure resembling Campylobacter spp.
\end{abstract}

proliferative enteritis; swine; Campylobacter species; streptavidin; immunoperoxidase; immuno-gold.

\section{Introduction}

Intestinal adenomatosis of swine is a common condition, affecting young pigs after weaning. The condition has been reported from many parts of the world, first in the U.S.A. (Biester \& Schwarte 1931, Dodd 1968), and later also from several countries in Europe (Emsbo 1951, Rowland \& Rowntree 1972, Jonsson \& Martinsson 1976, Landsverk \& Nordstoga 1981). The aetio- logy of the disease still remains obscure, however.

Intestinal adenomatosis is characterized by a proliferation of immature epithelial cells, absence of goblet cells in altered epithelial areas and the presence of mitotic figures at all levels of the epithelium. Electron microscopic studies reveal curved bacteria lying free within the cytoplasm of altered epithelial cells (Rowland \& Lawson 1974, Jonsson 
\& Martinsson 1976, Landsverk \& Nordstoga 1981, Lomax \& Glock 1982).

Based on immunofluorescent studies, Campylobacter sputorum subsp. mucosalis and Campylobacter hyointestinalis have been suggested as causes of the disease (Rowland \& Lawson 1974, Chang et al. 1984). Illustrating the still unresolved situation, other unidentified antigens is claimed to be present in adenomatous epithelium (Lawson et al. 1985, Lawson \& McOrist 1988).

Efforts to isolate infective agents, moreover, have been inconsistent (Rowland \& Lawson 1975, Jønsson \& Martinsson 1976, Landsverk \& Nordstoga 1981). Although C. sputorum subsp. mucosalis and $C$. hyointestinalis have been isolated from swine with intestinal adenomatosis, another group of campylobacters, the catalase-positive, thermotolerant campylobacters (Campylobacter jejuni and Campylobacter coli) are regularly isolated from swine with enteric diseases (Doyle 1944, Hamdy \& Glenn 1974, Taylor \& Olubunmi 1981, Gebhart et al. 1983), including pigs with intestinal adenomatosis (Lawson \& Rowland 1974, Gebhart et al. 1983), but also from normal swine (Rosef $\mathrm{et}$ al. 1983).

Transmission experiments have been equally inconclusive. Thus, inoculation with pure cultures of $C$. sputorum subsp. mucosalis (Roberts et al. 1980a, Roberts et al. 1980b, Lomax et al. 1982a, Lomax et al. 1982b, Boosinger et al. 1985) or C. hyointestinalis (Boosinger et al. 1985) has not consistently reproduced the typical field diseases of intestinal adenomatosis in the pig.

With this background, we found that a reexamination of possible aetiological factors using immuno-histochemical and -cytochemical techniques was warranted. We used sera produced against various species of campylobacters in an effort to identify the causative agent of the disease.

\section{Materials and methods}

\section{Specimen collection}

Intestinal tissue from the ileum and colon of 11 pigs which showed typical histological alterations of intestinal adenomatosis was examined. Affected intestinal areas revealed the presence of intracellular curved organisms in the apical cytoplasm of altered cells, using a silver impregnation technique (Young 1969).

Specimens were either collected immediately after death or during anaesthesia with $5 \%$ pentobarbital. Sections were collected after injection of the fixative into the intestinal lumen and were sampled from different levels of the ileum and colon.

Controls were 3 weanling pigs and one 3 week old pig, all clinically healthy without proliferative intestinal alterations.

Tissue preparations for immuno-histochemical studies

Intestinal samples for the avidin-biotin-complex $(\mathrm{ABC})$ method, were fixed in $10 \%$ neutral buffered formalin, processed routinely and embedded in paraffin.

Specimens for the streptavidin immunoperoxidase technique were placed with the mucosal side down onto specimens of liver tissue, attached to corrugated cardboard with pins, frozen in monochlorodifluoro methane (Prestogas ${ }^{8}$ ), chilled with liquid nitrogen, wrapped in aluminium foil and stored at $-70^{\circ} \mathrm{C}$ until examination.

\section{Tissue preparations for immuno-cytoche-} mical studies

Small pieces, $0.5-1 \mathrm{~mm}^{3}$, of diseased specimens were fixed in $8 \%$ formaldehyde. The fixed tissues were trimmed and placed in 2.3 $\mathrm{mol} / \mathrm{l}$ sucrose in phosphate buffered saline (PBS) for $30 \mathrm{~min}$. The tissue blocks were frozen in liquid nitrogen and cut on a Sorvall cryoultramicrotome at a temperature of 
$-90^{\circ} \mathrm{C}$. Sections were transferred to copper grids, contained in a drop of sucrose. Grids were floated on drops of PBS containing $10 \%$ fetal calf serum (FCS) on ice before antibody labelling.

\section{Bacterial smears}

Colonies of C. sputorum subsp. mucosalis, C.hyointestinalis, C.jejuni serotypes LAU 3, PEN 17, PEN 21, PEN 25 and C. coli, serotype LAU 44 were covered on glass slides and fixed over a gas flame.

\section{Production of bacterial antigens}

Thermotolerant campylobacters. Strains were stored at $-70^{\circ} \mathrm{C}$ in heat-inactivated horse serum with $17 \%$ glycerol. Strains were grown on blood agar plates for $48 \mathrm{~h}$. Plates were incubated at $42^{\circ} \mathrm{C}$ in anaerobic jars without catalysts, using gas-generating sachets (no. BR 38; Oxoid Ltd., Basingstoke, Hampshire, England) to achieve the correct microaerobic atmosphere. The criteria for identification, biochemical and serological classification have been outlined previously (Rosef et al. 1983).

C. sputorum subsp. mucosalis and C. hyointestinalis. Strains of C. sputorum subsp. mucosalis (253/72) (NCTC 11000) and $C$.hyointestinalis (NCTC 11562) were subcultured on blood agar plates after storage at $-70^{\circ} \mathrm{C}$ in glycerol-broth with $10 \%$ inactivated horse serum. The plates were incubated for $48 \mathrm{~h}$ at $37^{\circ} \mathrm{C}$ in jars where $10 \%$ of the atmosphere had been replaced by a gas mixture composed of $11.5 \% \mathrm{CO}_{2}$ and $88.5 \% \mathrm{H}_{2}$.

\section{Production of rabbit antisera}

Thermotolerant campylobacters. Five different unabsorbed rabbit antisera were used, which were prepared at the University Hospital of St. Pierre, Microbiology laboratory in Brussels, (courtesy of Dr. S. Lau- wers). Antisera were prepared in rabbits by subcutaneous injection of living bacteria, followed by 3 intravenous injections with an interval of 3 days (Kapperud et al. 1984).

Sera were diluted to a concentration of $1: 800$ for the use in immuno-histochemical studies and to the concentration of 1:50 in immuno-cytochemical studies.

C. sputorum subsp. mucosalis and C. hyointestinalis. Antigens were harvested in phosphate-buffered saline (PBS, pH 7.0) with $0.3 \%$ formalin and filtered through sterile gauze. The filtrates were centrifuged at $121 \mathrm{~g}$ for $5 \mathrm{~min}$., and the pellets were removed. The supernatants were washed 3 times in PBS/formalin with sentrifugation at $3.020 \mathrm{~g} \mathrm{(30} \mathrm{min.)} \mathrm{and} \mathrm{suspended}$ in PBS to optical density 0.5 at $525 \mathrm{~nm}$.

One rabbit was injected intravenously twice a week for 3 weeks with a standardized suspension containing $C$. sputorum subsp. mucosalis. The doses of injections were 1,1 , $1.5,1.5,2$ and $2 \mathrm{ml}$. The rabbit was bled 6 days after the last injection.

Another rabbit was injected intravenously twice a week for 3 weeks with a standardized suspension containing C.hyointestinalis. The doses of injections were 1, 2, 2, 4 and 4 $\mathrm{ml}$. The rabbit was bled 7 days after the last injection.

Merthiolat was added to the sera at a concentration of 1:10.000.

Sera were diluted to a concentration of $1: 800$ for the use in immuno-histochemical studies and to the concentration of 1:50 in immuno-cytochemical studies.

Normal rabbit serum. Normal rabbit serum served as a negative control serum.

\section{Immunoperoxidase methods}

The avidin-biotin-complex (ABC) was used in the immunoperoxidase test of the formalin-fixed, paraffin embedded specimens. Vectastain ABC Kit (Vector Laboratories, 
California 94010, U.S.A.) was used. Biotinylated goat antibody to rabbit immunoglobulins was the secondary antibody. The technical procedure has been described elsewhere (Eriksen et al. 1990).

Frozen sections were examined by the streptavidin immunoperoxidase technique, using formol-calcium fixation as reported (Landsverk 1987).

\section{Protein A gold method}

Ultra-cryo-sections were treated with 0.002 $\mathrm{mol} / \mathrm{l}$ glycine in PBS for $10 \mathrm{~min}$ in order to "quench" free aldehyde groups.

The grids were then placed on drops of primary antisera for $30 \mathrm{~min}$ at room temperature. The antiserum used was against $C$. jejuni, serotype PEN 21. Grids were then washed in PBS and incubated with diluted biotinylated goat antibody to rabbit immunoglobulins for $30 \mathrm{~min}$. After washing in PBS, the sections were incubated for $20 \mathrm{~min}$ with protein A gold $7 \mathrm{~nm}$ in $5 \%$ FCS/PBS. The sections were then washed in PBS and distilled water and exposed for uranyl acetate oxalate, pH 7.0 for $5 \mathrm{~min}$. Subsequently, sections were washed in distilled water for 3 min and treated with $2 \%$ metyl cellulose and $3 \%$ uranyl acetate on ice in $10 \mathrm{~min}$ before being dryed in a chamber containing silica gel for some min.

Sections were then examined in a Jeol $100 \mathrm{~S}$ electron microscope.

\section{Results \\ Bacterial smears}

The bacterial smears stained strongly with their homologous antisera, but were not stained by the normal rabbit serum.

\section{Immuno-histochemical studies of intestinal adenomatosis}

The results with both formalin-fixed, paraffin-embedded sections and cryostate sections were identical.

Thus, the sera against $C$. sputorum subsp. mucosalis and $C$. hyointestinalis were negative in all cases. Antisera against $C$. jejuni and $C$. coli gave a positive reaction in all of the 11 cases in one or more sections from the altered segments of the intestine, although intensity of staining varied somewhat.

No staining was seen in parallel sections exposed to normal rabbit serum.

In cases of positive reaction, staining was seen in altered epithelial cells at all levels of the crypts. The staining was restricted to the apical part of the cytoplasm (Fig. 1). Positive organisms usually appeared in large numbers in the cells, but their shape was not readily apparent. In areas of less intense infection, the organisms appeared to be curved (Fig. 2). Positive organisms were seen in the lumen of some crypts. Some leucocytes of the lamina propria also stained. Adjacent tissue with normal differentiation of goblet cells and apparent normal morphology of other brush border cells showed no staining of the apical cytoplasm.

Figure 1. Intestinal adenomatosis, ileum. Paraffin section incubated with Campylobacter jejuni, serotype LAU 3 antiserum. Proliferating crypts show positive organisms in the apical cytoplasm of the epithelial cells. $\times 425$.

Figure 2. Intestinal adenomatosis, colon. Cryosection incubated with Campylobacter jejuni, serotype PEN 21 antiserum. Positive organisms in the apical cytoplasm of epithelial cells. Note the curved organisms, resembling Campylobacter. $\times 1062$. 
$K$. Eriksen, T. Landsverk, B. Gondrosen and $J$. Vormeland: Immuno-histochemical and -cytochemical evidence suggesting the presence of Campylobacter jejuni and Campylobacter coli in cases of porcine intestinal adenomatosis.
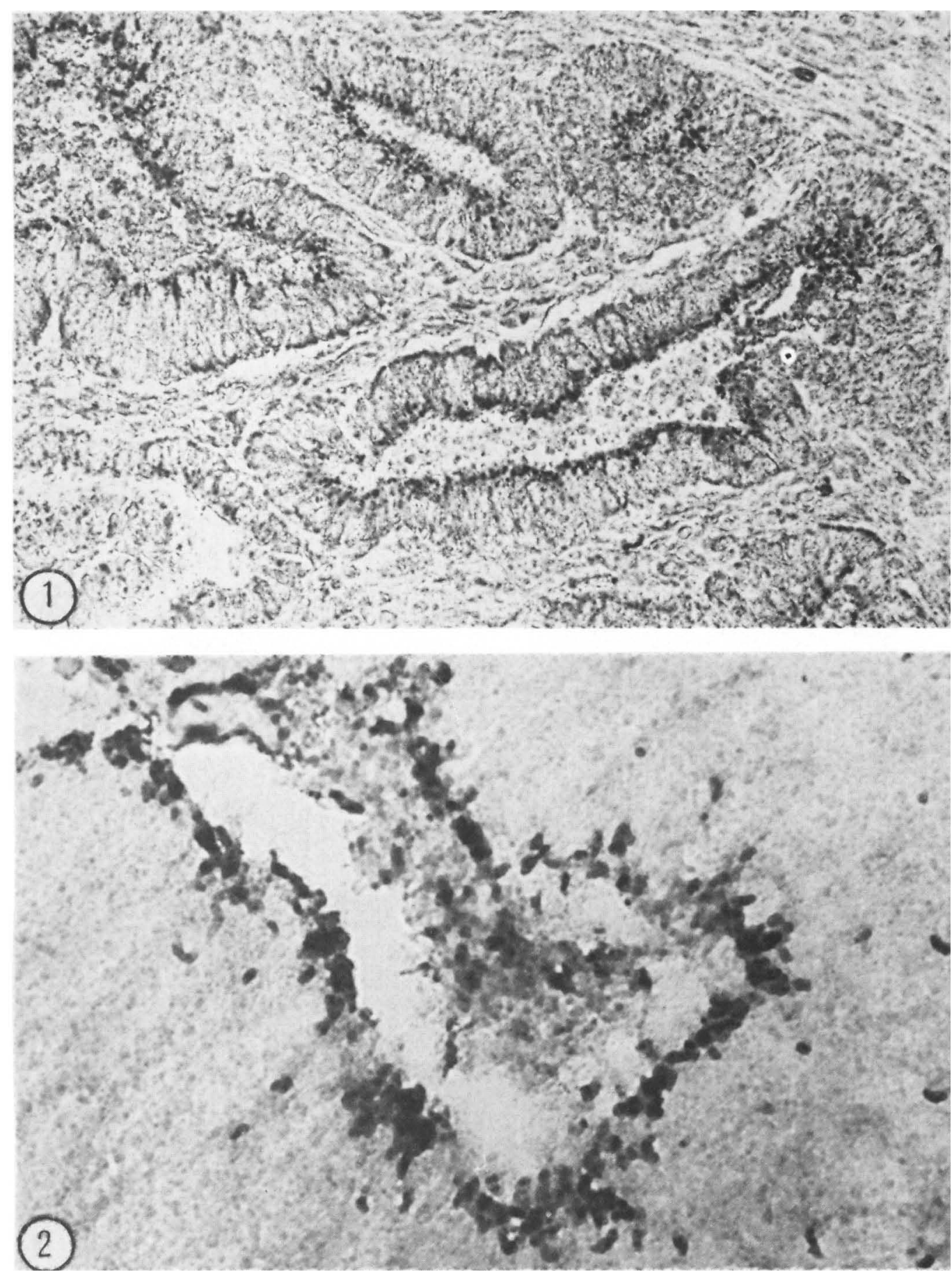

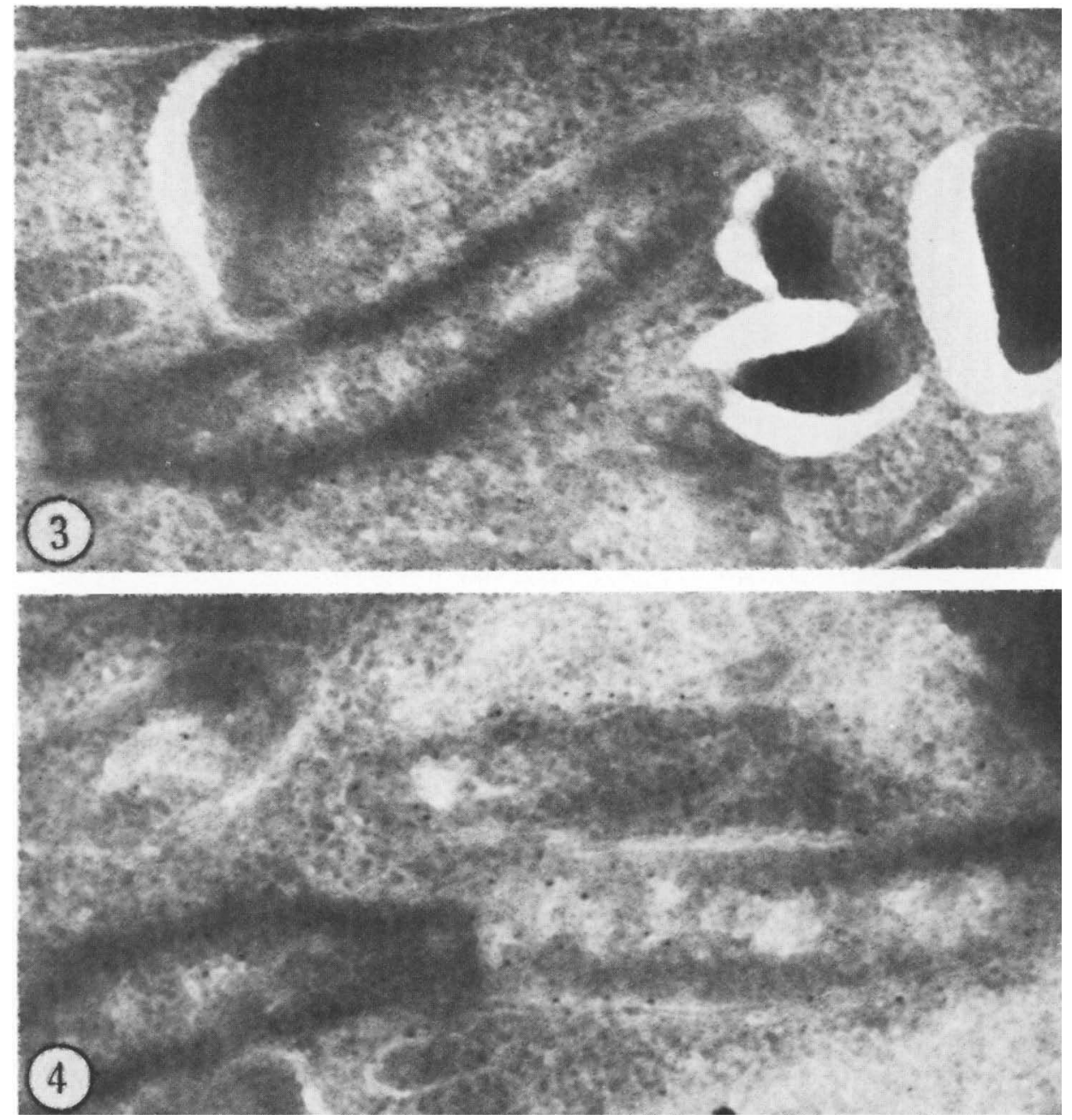

Figure 3. Intestinal adenomatosis, ileum. Ultracryosection labeled with Campylobacter jejuni, serotype PEN 21 antiserum. Electron-dense gold particles are distributed over organisms lying in the cytoplasm of altered epithelial cells. $\times 20.000$.

Figure 4. Intestinal adenomatosis, ileum. Ultracryosection incubated with antiserum against Campylobacter jejuni, serotype PEN 21. Curved organisms, resembling Campylobacter, are being labeled by gold particles. $\times 20.000$. 
Immuno-histochemical studies of control animals

No staining was seen in epithelial cells in the controls, but positive organisms were sometimes seen in the lumen of the intestine and the upper crypt lumen.

\section{Immuno-cytochemical studies of intestinal adenomatosis}

Several isolated gold particles of high electron density were present over the intracellular organisms lying in the cytoplasm of altered epithelial cells (Figs. 3 and 4). The background staining was low.

\section{Discussion}

In the present study, intestinal sections from cases of intestinal adenomatosis stained strongly with antisera against the thermotolerant group of campylobacters, namely $C$. jejuni and $C$. coli. Our studies also show that the activity of the antisera against $C$. jejuni, serotype PEN 21 was directed against the bacteria lying in the cell cytoplasm of altered epithelial cells and not against other cellular components.

In contrast with other studies (Chang et al. 1984), antisera of C. sputorum subsp. mucosalis and $C$. hyointestinalis did not react in sections from altered tissue. This could be due to a low activity of the particular serum, but all antisera stained strongly the homologous bacteria in glass smears.

Bacteriological studies of healthy pigs in Norway have shown that thermotolerant campylobacters can be isolated from the intestinal contents in $100 \%$ of the animals (Rosef et al. 1983). Thus, this may explain the presence of positive luminal organisms which we found in the controls in the present study. Although thermotolerant campylobacters have been considered as apathogenic in pigs, little is known about the relative virulence of different strains. Recent reports indicate that $C$.jejuni and $C$.coli possess an assortment of virulence factors, including an enterotoxin, a cytotoxin and possibly also an unknown invasive factor (Walker et al. 1986).

The present results thus differ conspicuously from studies in other countries, where C. sputorum subsp. mucosalis and C. hyointestinalis have been suggested as causes of intestinal adenomatosis in the pig (Rowland \& Lawson 1974, Lomax et al. 1982a,b, Chang et al. 1984). Little attention, however, seems to have been given to the examination of the relative importance of $C$. jejuni and $C$. coli. Although it is possible that different aetiological agents may operate in different countries, we think that a condition as special as intestinal adenomatosis is most likely to have a restricted aetiology, possibly a single bacterial strain. The present results appear to justify the conclusion that an agent having antigens in common with $C$.jejuni and $C$. coli, and different from $C$. sputorum subsp. mucosalis and $C$. hyointestinalis, may be associated with intestinal adenomatosis in swine in Norway.

\section{Acknowledgement}

The authors wish to thank Ulla Kinde at the Electronmicroscopical Unit for Biological Sciences at the University of Blindern, Oslo, for her help in the immuno-cytochemical studies.

\section{References}

Biester $H E$, Schwarte $L H$ : Intestinal adenoma in swine. Amer. J. Path. 1931, 7, 175-185.

Boosinger TR, Thacker HL, Armstrong CH: Campylobacter sputorum subsp. mucosalis and Campylobacter hyointestinalis infections in the intestine of gnotobiotic pigs. Amer. J. vet. Res. 1985, 46, 2152-2156.

Chang K, Kurtz HJ, Ward GE, Gebhart CJ: Immunofluorescent demonstration of Campylobacter hyointestinalis and Campylobacter sputorum subsp. mucosalis in swine intestines 
with lesions of proliferative enteritis. Amer. J. vet. Res. 1984, 45, 703-710.

Dodd DC: Adenomatous intestinal hyperplasia (proliferative ileitis) of swine. Path. Vet. 1968, 5, 333-341.

Doyle LP: A Vibrio associated with swine dysentery. Amer. J. vet. Res. 1944, 5, 3-5.

Emsbo $P$ : Terminal of regional ileitis in swine. Nord. Vet.-Med. 1951, 3, 1-28.

Eriksen $K$, Landsverk $T$, Bratberg B: Morphology and immunoperoxidase studies of intestinal adenomatosis in the blue fox. J. comp. Pathol. 1990, 102, 265-278.

Gebhart CJ, Ward GE, Chang K, Kurtz HJ: Campylobacter hyointestinalis (new species) isolated from swine with lesions of proliferative ileitis. Amer. J. vet. Res. 1983, 44, 361367.

Hamdy AH, Glenn MW: Transmission of swine dysentery with Treponema hyodysenteriae and Vibrio coli. Amer. J. vet. Res. 1974, 35, 791-797.

jonsson L, Martinsson K: Regional ileitis in pigs. Morphological and pathogenetical aspects. Acta vet. scand. 1976, 17, 223-232.

Kapperud G, Lassen J, Lauwers $S$, Rosef $O$ : Serotyping and biotyping of Campylobacter jejuni and Campylobacter coli from sporadic cases and outbreaks in Norway. J. clin. Microbiol. 1984, 19, 157-160.

Landsverk T: Cryptosporidiosis and the follicleassociated epithelium over the ileal Peyer's patch in calves. Res. Vet. Sci. 1987, 42, 299306.

Landsverk $T$, Nordstoga $K$ : Intestinal adenomatotosis in pigs. A patho-morphological investigation. Nord. Vet.-Med. 1981, 33, 77-80.

Lawson GHK, McOrist S: Reproduction of proliferative enteritis in gnotobiotic pigs. Proc. 10th Congr. Int. Pig Vet. Soc. 1988, p. 132.

Lawson GHK, Rowland $A C$ : Intestinal adenomatosis in the pig: A bacteriological study. Res. Vet. Sci. 1974, 17, 331-336.

Lawson GHK, Rowland AC, MacIntyre N: Demonstration of a new intracellular antigen in porcine intestinal adenomatosis and hamster proliferative ileitis. Vet. Microbiol. 1985, 10, 303-313.
Lomax $L G$, Glock RD: Naturally occurring porcine proliferative enteritis: Pathologic and bacteriologic findings. Amer. J. vet. Res. 1982, 43, 1608-1614.

Lomax LG, Glock RD, Hogan JE: Experimentally induced porcine proliferative enteritis in specific-pathogen-free pigs. Amer. J. vet. Res. 1982a, 43, 1615-1621.

Lomax LG, Glock RD, Harris DL, Hogan JE: Porcine proliferative enteritis: Experimentally induced disease in cesarean-derived colostrumdeprived pigs. Amer. J. vet. Res. 1982b, 43, 1622-1630.

Roberts L, Lawson GHK, Rowland AC: The experimental infection of neonatal pigs with Campylobacter sputorum subspecies mucosalis. Res. Vet. Sci. 1980a, 28, 145-147.

Roberts L, Lawson GHK, Rowland $A C$ : The experimental infection of pigs with Campylobacter sputorum subspecies mucosalis. Weaned pigs with special reference to pharmacologically mediated hypomotility. Res. Vet. Sci. 1980b, 28, 148-150.

Rosef $O$, Gondrosen B, Kapperud $G$, Underdal B: Isolation and characterization of Campylobacter jejuni and Campylobacter coli from domestic and wild mammals in Norway. Appl. Environ. Microbiol. 1983, 46, 855-859.

Rowland $A C$, Lawson $G H K$ : Intestinal adenomatosis in the pig: Immunofluorescent and electron microscopic studies. Res. Vet. Sci. 1974, 17, 323-330.

Rowland AC, Lawson GHK: Porcine intestinal adenomatosis: A possible relationship with necrotic enteritis, regional ileitis and proliferative haemorrhagic enteropathy. Vet. Rec. 1975, 97, 178-180.

Rowland AC, Rowntree PGM: A haemorrhagic bowel syndrome associated with intestinal adenomatosis in the pig. Vet. Rec. 1972, 91, 235-241.

Taylor DJ, Olubunmi PA: A re-examination of the role of Campylobacter fetus subspecies coli in enteric disease of the pig. Vet. Rec. 1981, 109, 112-115.

Walker RI, Caldwell MB, Lee EC, Guerry P, Trust TJ, Ruiz-Palacios GM: Pathophysio- 
logy of Campylobacter enteritis. Microbiol. Rev. 1986, 50, 81-94.

Young BJ: A reliable method for demonstrating spirochaetes in tissue sections. J. med. Lab. Technol. 1969, 26, 248-252.

\section{Sammendrag \\ Immun-histokjemisk og -cytokjemisk indikasjon på tilstedevarelsen av Campylobacter jejuni og Campylobacter coli ved intestinal adenomatose. Antisera mot ulike Campylobacter species ble brukt i immun-histokjemiske og -cytokjemiske studier. Avidin-biotin-complex (ABC) og strepta- vidin immunperoksydase metoder ble utført på formalinfikserte, paraffininnstøpte snitt og på fry- sesnitt fra tilfeller av intestinal adenomatose hos gris. De benyttede antisera ble produsert på kanin ved intravenøs eller subkutan injeksjon av levende}

eller formalin behandlede bakterier. Antisera mot ulike serotyper av termotolerante, katalase positive Campylobacter, Campylobacter jejuni og Campylobacter coli ga positiv reaksjon. Den positive reaksjonen ble funnet $i$ forandrede epitelceller både $\mathrm{i}$ kolon og $\mathrm{i}$ ileum og var begrenset til den apikale delen av cytoplasmaet. Det var ingen reaksjon i områder med tilsynelatende normal epitelcelle morfologi og differensiering av begerceller. Antisera mot Campylobacter sputorum subsp. mucosalis og Campylobacter hyointestinalis ga ingen reaksjon. Immun-cytokjemiske undersøkelser med antiserum mot Campylobacter jejuni, serotype PEN 21 viste at den positive reaksjonen i adenomatøst omdannede epitelceller var lokalisert til intracellulære bakterier og ikke til andre cytoplasmatiske komponenter.

(Received July 10, 1989; accepted February 1, 1990).

Reprints may be requested from: Karin Eriksen, the Department of Pathology, Norwegian College of Veterinary Medicine, P. O. Box 8146, Dep., N-0033 Oslo 1, Norway. 